\title{
Canada isn't making the most of DIY tests for HPV
}

\author{
Cite as: CMAJ 2018 March 12;190:E304. doi: 10.1503/cmaj.109-5573
}

Posted on cmajnews.com on Feb. 21, 2018.

tripped from the waist, legs splayed in stirrups, many women find cervical cancer screening invasive and embarrassing, which may lead them to delay or avoid testing.

Last year, Health Canada approved the first self-testing kits for strains of human papilloma virus (HPV) that cause most cases of cervical cancer. Self-testing is potentially a "really great tool to offer women who just aren't engaging in screening," says Dr. Sheila Dunn, director of research at the Family Practice Health Centre at Women's College Hospital in Toronto. But until these do-it-yourself kits are incorporated into official screening programs, their usefulness may be limited.

Screening for HPV infection more accurately detects precancerous changes in the cervix than pap smears. And unlike a pap test, which requires a doctor to scrape cells from a woman's cervix to check for abnormalities, HPV testing can be done on a vaginal swab that a woman takes herself. Self-sample tests are slightly less sensitive and specific than HPV testing performed by professionals, but they're a valid alternative for women who wouldn't be screened otherwise, says Dunn. Women in remote areas, those past menopause, and newcomers to Canada are commonly under-screened, she explains.

A recent Canadian review found strong evidence that self-sample HPV tests increase participation in screening among hard-toreach women. The authors also concluded that it is unlikely self-sampling will lead to additional costs for screening programs. However, "the groups that are underscreened are often the groups that need it the most, and are unaware of it as an option," Dunn says.

"Offering this option within a populationbased program would increase awareness," says Brianne Wood, a clinical research fellow

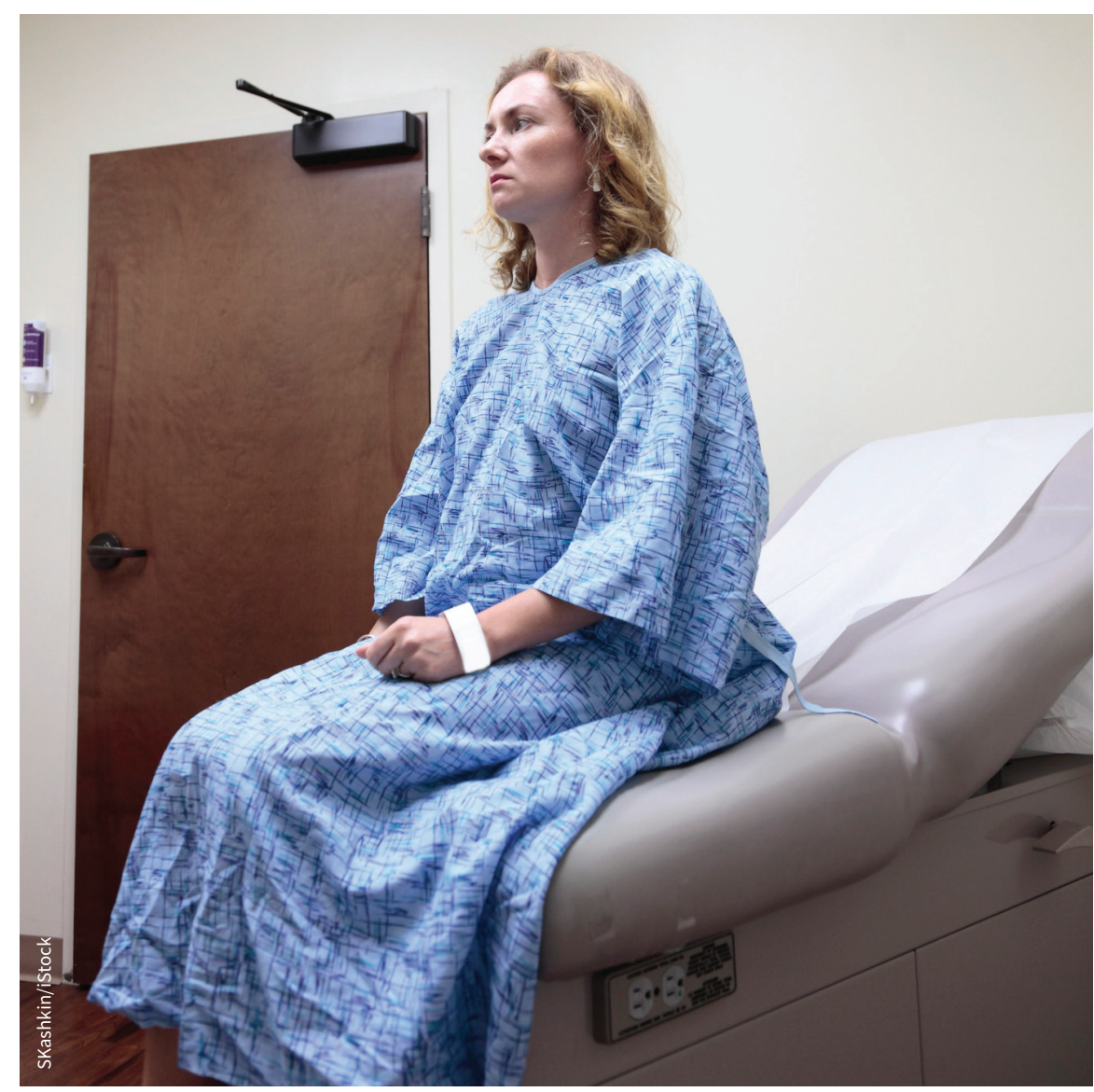

Self-sampling HPV tests are now available in Canada, but fall outside cancer screening programs.

at Eve Medical, the company that launched the self-sample tests in Canada. "Women will have different reasons for different preferences, but it is important that they have a choice," she says.

Self-sample HPV tests aren't offered through established screening programs or covered by public health plans. This means women have to pay for the tests out-of-pocket. But beyond the issue of choice, Dunn argues that excluding selftesting from screening programs undermines those programs. "The advantages of having the whole population engaged in a population-based screening program are lost when women do this outside of the program," she says.

Australia and the Netherlands were the first countries to integrate self-sample HPV tests into cervical cancer screening programs. British Columbia, Manitoba, Quebec and Ontario are considering HPV testing as a primary screening tool, but self-sampling hasn't been addressed.

"It would be nice it was offered to any woman as one of the alternatives, but I don't think we're quite there yet," says Dunn.

Yana Fedyanova, CMAJ 